\title{
'Abd al Wāḥid ben 'Ali al Tamimi al Marrakuši
}

\section{El Briga}

\section{(2) OpenEdition}

\section{Journals}

\section{Édition électronique}

URL : http://journals.openedition.org/encyclopedieberbere/783

DOI : $10.4000 /$ encyclopedieberbere.783

ISSN : 2262-7197

\section{Éditeur}

Peeters Publishers

\section{Édition imprimée}

Date de publication : 1 novembre 1984

Pagination : 73

ISBN : 2-85744-201-7

ISSN : 1015-7344

\section{Référence électronique}

C. El Briga, « 'Abd al Wāhid ben 'Ali al Tamimi al Marrakuši », Encyclopédie berbère [En ligne], 1 | 1984, document A14, mis en ligne le 01 décembre 2012, consulté le 05 octobre 2020. URL : http://

journals.openedition.org/encyclopedieberbere/783 ; DOI : https://doi.org/10.4000/ encyclopedieberbere.783

Ce document a été généré automatiquement le 5 octobre 2020.

(c) Tous droits réservés 


\title{
'Abd al Wāhid ben 'Ali al Tamimi al Marrakuši
}

\author{
C. El Briga
}

Historien de la dynastie des Almohades né à Marrakech en 581/1185. Il étudia à Fes puis en Espagne où il fréquenta la cour du gouverneur almohade de Séville. En 631/1217 il partit en Égypte et y séjourna quelques années. Il fit le pélerinage à la Mecque en 620/1223. Ce ne fut que l'année suivante qu'il rédigea son histoire des Almohades ( $\mathrm{Al}$ mu'jib fi talkhīs akhbār al Maghrib).

\section{BIBLIOGRAPHIE}

AL MARRAKUŠI. The history of Almohades. Trad. Dozy, Leyde 1881. Trad. Fagnan, Alger, 1873. Voir Almohades.

INDEX

Mots-clés : Biographie, Maroc, Moyen Âge 